\title{
RESÍDUOS DO SINTOMA E CRÍTICA DO SENTIDO NA FILOSOFIA E NA PSICANÁLISE
}

TEIXEIRA, Antônio M. R. A soberania do inútil e outros ensaios de psicanálise e cultura. São Paulo: Annablume, 2007.

\author{
Gilson Iannini* \\ gilsoniannini@yahoo.com.br
}

Muita gente pode não perceber que algumas obras que carregamos para cima e para baixo são, na verdade, coletâneas organizadas com vistas a dar maior visibilidade a textos publicados de forma dispersa em veículos de circulação mais restrita, como revistas especializadas e anais de congressos. Os resultados desses tipos de agrupamentos são heterogêneos, indo desde mera compilação desprovida de unidade de tema ou de método até a realização de obras nas quais a dispersão original fica totalmente camuflada atrás da unidade sintética assim produzida. Os ensaios de Antônio Teixeira coligidos em sua $A$ soberania do inútil ficam em algum lugar bem perto dessa última extremidade. Há uma surpreendente unidade tanto nos eixos temáticos subjacentes, quanto no estilo de tratamento de problemas. Com efeito, de ponta a ponta, o livro é marcado por uma combinação de traços dificilmente conciliáveis: ineditismo da abordagem e rigor conceitual. 


\section{Linhas de fuga: uma ensaística não esteticizante}

Não por acaso, o livro começa por uma análise do que vem a ser um ensaio, a partir das considerações de Max Bense, Lukács e Adorno, para então propor coordenadas para uma ensaística propriamente psicanalítica. Grosso modo, pode-se dizer que na ciência-, o trabalho da forma é neutralizado em função da primazia do conteúdo. No ensaio, ao contrário, combinam-se "o cuidado estético da forma e a perspectiva objetivante da exposição conceitual" (p. 17). Mas, em consonância com a crítica que Žižek fez da esteticização universalizante própria ao desconstrutivismo e ao pós-estruturalismo, Antônio Teixeira sublinha que esse cuidado com a forma não pode ser um fim em si mesmo. É nesse sentido que se coloca a necessidade de ruptura do envelope estético do ensaio para fazer "surgir o engajamento ético do autor" (p. 20). Ao tratar o conceito como significante, e não como entidade de sentido estável alheia ao movimento e à singularidade, bem como às peculiaridades do objeto, o autor dá provas da mais estrita observância ao melhor lacanismo. É isso que permite mostrar que o engajamento ético que ele suscita é, embora o autor não o diga, eminentemente clínico. Uma clínica que se configura como dispositivo de tratamento do singular que não se deixa levar pelo elogio cego da singularidade irredutível, nem se deixa seduzir pelo formalismo vazio.

Esse seu Prólogo poderia ser mera profissão de fé desacompanhada de conseqüências. O que não é definitivamente o caso. Desde o primeiro ensaio, acerca de uma pretensa vocação da cultura brasileira para o chiste, o autor coloca à prova o método e o estilo propostos, criando, de saída, perspectivas promissoras. Mais do que os resultados de sua análise, cumpre observar a estratégia mobilizada. Diferentemente dos cânones escriturais próprios a uma certa psicanálise que não esconde seu gosto por se deixar colonizar pelo velho continente, Antônio Teixeira, em sua análise do chiste, esboça a incorporação de métodos - ou, quase diríamos, de malícias - próprias ao modernismo brasileiro. No esforço de responder à pergunta sobre se existiria uma vocação para o chiste na cultura brasileira, efetua-se uma série de transformações sucessivas da pergunta até desembocar na indagação acerca da existência no Outro de um apelo "por um gesto que coloca em causa a consistência de suas regras" (p. 27). A forma do argumento é exemplar do que tentamos aqui indicar. Trata-se da passagem do personagem de Diderot, o sobrinho de Rameau, ao herói sem nenhum caráter, Macunaíma. "Síntese impossível do Brasil", o personagem de Mário de Andrade, poderia ser visto, por sua preguiça afirmativa, como um "contraponto frontal com a lei moral kantiana". Em sua "recusa alegre" do jogo de pantomimas a que as convenções sociais, em última análise, se reduzem, "não se trata de opor a realidade à farsa que a 
sociedade representa. A realidade é ela mesma tratada como uma farsa, como uma pantomima". Ao contrário do que poderia parecer à primeira vista, não se trata de fuga da realidade, mas da criação de uma linha de fuga. Por isso, nessa recusa cômica da realidade, há uma "vocação essencialmente política" (p. 30).

Esta vocação política pode ser exemplificada pela seguinte afirmação: "é da boca do sujeito parvo que saem (...) as verdades que não são somente toleradas, mas colocadas em função de sua bufonaria" (p. 30). Ao incorporar a máxima segundo a qual é preciso "prestar-se à besteira, mas sem se consagrar a ela" como principal horizonte de sua ensaística, Antônio Teixeira enfrenta o risco de dar voz a verdades fora do sentido. Refiro-me à sua estratégia de indexação paradoxal, e por vezes paródica, do caso ao conceito. Na contramão do intelectual reacionário que tenta salvar a verdade na estabilidade do enunciado, "elidindo o risco e o jogo da enunciação", Teixeira assume esse risco quando aposta nessa forma de escrita que restabelece a necessária tensão entre a universalidade do discurso conceitual e a singularidade do caso. $\mathrm{O}$ recurso parvo à anedota deixa de ser fortuito, porque serve para desnudar o que há de irrisório em tentar hipostasiar o discurso conceitual sem levar em conta o hiato inelidível com o não-conceitual. É isso que explica a profusão de exemplos nada corriqueiros em livros de filosofia e psicanálise: não apenas a preguiça afirmativa de Macunaíma, mas o "marido contrariado" pelas exigências da "patroa", o asco da criança pela nata, a recusa de Groucho Marx em fazer parte do clube que o aceitasse como sócio, as boutades de Woody Allen, a alusão inconfessada a Tim Maia na figura por ele referida do proxeneta apaixonado etc.

Ousadia e rigor são duas palavras difíceis de combinar, mas que aqui encontram suficiente equilíbrio. A ousadia está presente em diversos níveis: na escolha de temas, como a existência de uma vocação para o chiste na cultura brasileira ou a inextirpável dimensão de besteira no discurso, inclusive o psicanalítico; mas principalmente essa ousadia está presente nas perspectivas adotadas para problemas psicanalíticos, como a reflexão de Bataille sobre o inútil e a análise sartriana do viscoso a fim de pensar o resíduo do tratamento analítico, ou a ética de Espinosa para tematizar o fenômeno clínico da depressão. Essa mesma ousadia está presente ainda nos exemplos que ventilam a exposição conceitual, cuja função analisamos acima.

Mas essa ousadia nunca é desacompanhada de uma argumentação sólida e de um rigor conceitual invejáveis, o que, por si só, destaca o livro diante desse crescimento vertiginoso do número de publicações no Brasil. Uma virtude notável dessa solidez é relativa ao modo como o autor se apropria 
de referências filosóficas. Teixeira sabe extrair cirurgicamente o que importa à sua argumentação, sem se perder por discussões estéreis ou paráfrases intermináveis, sem, no entanto, violentar a especificidade própria a cada autor referido e sem reduzir a história da filosofia a uma mera antecâmara da psicanálise. O diálogo da psicanálise com a filosofia é, na maioria das vezes, proveitoso para ambos os lados. Não se trata, quase nunca, do mero uso de referências eruditas destinadas a tornar o discurso elevado ou seja lá o que for. Salvo por uma referência desnecessária ao Sofista de Platão, em "Do Mesmo ao Outro sexo", e- talvez; de um recurso a Gödel, que, embora avalizado por nomes do quilate de um Badiou, mereceria melhor justificação na economia do argumento, todas as referências à filosofia são feitas de modo a suscitar o interesse tanto do psicanalista quanto do filósofo.

Combinados, ousadia e rigor incidem no apagamento deliberado dos limites entre o erudito e o prosaico. Se os ensaios aqui coligidos são atravessados de referências, sempre muito cuidadosas, a Espinosa, Kant, Bataille, Flaubert, Mário de Andrade, Deleuze, Foucault além, é claro, de Freud e Lacan, eles não deixam de aludir a Orígenes Lessa ou a Tim Maia... Esse apagamento de limites entre o prosaico e o erudito é acompanhado de uma variação de tom curiosa. Roberto Schwarz, na homenagem recente que prestou a Bento Prado Jr. no número 36 da revista Discurso, escreveu que a frase de Bento era "ligeiramente retórica e fora de moda, com miolo filosófico moderno". Poderíamos estender o comentário, que cabe como uma luva, para caracterizar a fraseologia própria a Antônio Teixeira. No entanto, a tonalidade do estilo, sempre cuidada e elegante, às vezes incomoda por uma sintaxe ligeiramente preciosista, principalmente quando se deixa elevar além de certos limites. É o preço a pagar pelas escolhas ousadas que faz. Mas esse detalhe fraseológico se mostra totalmente acessório diante das diversas qualidades já referidas. Isto posto, o livro deve ser comemorado como um belo exemplo do que há de mais atual e mais sofisticado na pesquisa brasileira, que nos coloca em pé de igualdade com o que há de melhor na produção internacional na área delimitada pelo confronto da filosofia com a psicanálise.

\section{Eixos temáticos}

Dois eixos atravessam o livro de ponta a ponta e emprestam unidade temática ao conjunto: o problema do resíduo sintomático de todo tratamento analítico e o que poderíamos chamar de crítica do sentido. Note-se que o primeiro tema é psicanalítico, ao passo que o segundo é eminentemente filosófico, embora a crítica do sentido aqui empreendida seja amplamente 
dependente da intervenção de Lacan no debate contemporâneo acerca da linguagem. O resíduo sintomático do tratamento é um tema de alta relevância clínica e constitui talvez o problema mais debatido nos dias de hoje. Lacan forjou o neologismo "sinthoma" (com th) para abordar o problema. E o fez através de uma complicada parceria da teoria matemática dos nós com a leitura das experiências literárias de James Joyce. Por seu turno, Teixeira faz isso através da exploração, até as últimas conseqüências, da noção freudiana de viscosidade da libido. É isso que realiza o ensaio que dá título ao livro. Mas o tema retorna em diversos outros momentos.

O segundo eixo que perpassa o livro diz respeito à crítica do caráter imaginário do sentido, ou, para dizer como o autor, da "rede ilusória do sentido" que informa o laço social. É esta crítica do sentido que funciona, a um tempo, como temática e como instrumento de análise de diversas formações culturais e problemas clínicos, como o chiste ou o lugar do pai na direção da cura. O texto que melhor realiza esse programa é "Do bom uso da besteira", em que se examina até que ponto é possível prescindir da dimensão pantomímica do discurso socialmente aceito. Aqui o autor realiza uma implacável crítica da "paixão conformista" que caracteriza a figura do "canalha", e explica porque esse "tipo menor" está votado ao sucesso em nossa sociedade contemporânea. É o canalha, figura de proa nas emissões televisivas de auto-ajuda e na política profissional, quem oferece aos sujeitos aquilo que eles pensam desejar; aquele que não poupa esforços em nos liberar da inquietude, oferecendo uma representação estável em que os sujeitos podem se contemplar. Eis porque a televisão, muitas vezes, é um espelho e o canalha, aquele que ilumina a encenação. Nesse ponto evidencia-se uma outra virtude recorrente dos ensaios recolhidos: eles não param por aí. Se o fizessem, estaríamos bem servidos com uma crítica do simulacro presente em nossas formações culturais, que conclamam os sujeitos a "consentir sem pensar", conforme a máxima besta. Mas isso não basta. Porque o preço a ser pago por quem abdica da avalanche de bobagens própria ao discurso comum é, justamente, o isolamento. Por isso, cumpre não resistir à besteira, ou à bobajada, além da conta. A pergunta que se impõe é, pois: é possível se servir inteligentemente da besteira? Inteligentemente, o autor recorre a Flaubert e ao "uso metódico da besteira hiperbólica para afrontar a besteira que lhe causa ojeriza". É desse uso metódico que deriva a divisa: "prestar-se à besteira, mas sem se consagrar a ela". Esse ensaio constitui não apenas uma referência importante para entendermos a ética lacaniana do bem-dizer, mas constitui ele próprio um exercício dessa ética. 
É na esteira dessa ética que podemos ressaltar uma característica, talvez insuspeitada, do livro. Ainda que o seu título não inclua a palavra clínica, os artigos nele contidos são marcados, de ponta a ponta, por uma sensibilidade clínica notável. E isso na melhor tradição dos textos de Lacan, nos quais os objetos de cultura e os exemplos filosóficos freqüentemente funcionam como casos clínicos, na medida que colocam à prova a universalidade do discurso teórico diante da singularidade do caso, e na medida que tensionam o conceito para fazê-lo dizer o seu máximo, limitando-o internamente. Não por acaso, os casos clínicos são raros na obra de Lacan. Mas isso não impede que o leitor pressinta o interesse clínico dos exemplos culturais e filosóficos utilizados. $\mathrm{O}$ mesmo se passa aqui. E não apenas em textos mais explicitamente voltados para questões clínicas, como "Dor de existir...", em que temos uma elucidativa abordagem da depressão, ou quando nos fornece lembretes técnicos relativos a condições para que a interpretação possa ser eficaz, ou ainda quando fornece uma via de acesso para o resíduo de uma análise. Não. Mesmo quando fala da preguiça afirmativa de Macunaíma ou do regime de exceção e do biopoder, estão em jogo impasses clínicos que o analista precisa enfrentar. Disso resulta seu interesse clínico. Interesse que não camufla, nem dissimula, em nenhum momento, aqueles impasses, relativos, por exemplo, à dificuldade em lidar com sintomas face ao declínio da função paterna na sociedade contemporânea.

Um exemplo magistral dessa estratégia, temos no artigo que dá título à coletânea. "Da soberania do inútil" parte desse objeto dessacralizado que é o utensílio, como metáfora daquilo que rompe com a perspectiva romântica de conhecimento, na qual havia ainda uma certa participação libidinal do sujeito com relação ao objeto. Através do circuito que liga o utensílio ao trabalho na forma da exterioridade e na figura do meio desprovido de finalidade, o homem torna-se, ele próprio, meio. A soberania do sujeito é solapada por sua inserção no "circuito da utilidade e do sentido". A essa lógica da ruptura com a imanência da natureza nada parece escapar, a não ser a própria noção de finalidade. Na visão de Bataille, só escapa a esse reenvio infinito o que é, não um meio para algo, mas um fim em si mesmo. Só é soberano aquilo que é inútil, aquilo que não serve, que não é meio para nada. Se é o trabalho que interrompe a intimidade do sujeito com o mundo, é o sacrifício que a restitui, na forma do sagrado. Mas o que isso tudo tem a ver com psicanálise? Não cabe aqui reconstruir todo o argumento, mas apenas indicar para onde ele nos conduz: à homologia da lógica acima descrita com a lógica lacaniana do desejo e de seu objeto. Para Freud, a satisfação sexual é um fim em si, portanto, o sexo não responde à lógica do trabalho e da exterioridade. Ao contrário, o sexo não se submete a nenhuma finalidade exterior à sua própria satisfação. Seguem-se 
as páginas talvez mais brilhantes do livro, relativas à análise da viscosidade da libido. Essas páginas, passando pela análise do nojo e da vergonha, como "diques destinados a represar a libido", nos levam até a idéia de um resíduo da adesão libidinal ao objeto. "O viscoso é portanto a revanche do em si que se opõe a seu uso: ele é o que resta do elemento do mundo de que eu acreditava poder dispor sem dele participar, com vista a uma finalidade exterior, na forma do utensílio" (p. 82). Como o autor relaciona isso ao "sinthoma" lacaniano de final de análise, deixo ao leitor o prazer de descobrir. 